\title{
Estradas que suportam distâncias: notas sobre exílio e pulsão de ficção em Terra Sonâmbula de Mia Couto
}

Jorge Henrique da Silva Romero

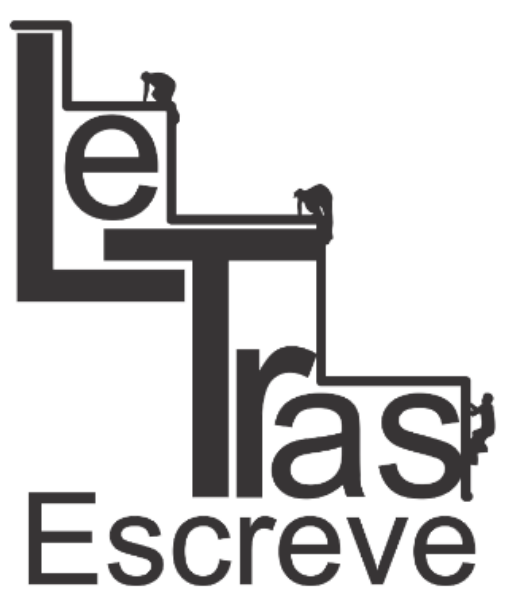

(ISSN 2238-8060)

Outro narrador, Ulisses, industrioso nas artes de enganar e exilado pelos deuses, ao chegar no reino dos Feácios, depois de errar pelos mares, proibido de retornar para casa e, portanto, condenado ao exílio, narra sua história na corte do rei Alcino; descreve o herói sua chegada à terra dos Lotófagos e dos muitos perigos que enfrentou durante o seu longo exílio:

No dezeno aos Lotófagos arribo, Que apascenta uma planta e flor cheirosa. Jantamos, feita aguada; envio arauto Com mais dois a inquirir de pão que gente Lá se nutria. Aos três em nada ofendem, Mas lhes ofertam loto; o mel provando, Os nossos o recado e a pátria esquecem, Querem permanecer para o gostarem. Constrangidos e em lágrimas os trago E amarro aos bancos; apressado os outros

https://periodicos.unifap.br/index.php/letras Macapá, v. 6, n. I, Io semestre, 2016. 
Sócios recolho, a fim que do regresso

A doçura falaz os não deslembre.

Em fila, a salsa espuma a remos ferem,

E dali pesarosos nos partimos. ${ }^{1}$

Loto é o doce mel do esquecimento. É precisamente o esquecimento a "grande tentação contra a qual luta a Odisseia inteira" (GAGNEBIN, 2006, p. 14). O episódio, acima referido, indica ainda, segundo a autora, que "a luta de Ulisses para voltar a Ítaca é, antes de tudo, uma luta para manter a memória e, portanto, para manter a palavra, as histórias, os cantos que ajudam os homens a se lembrarem do passado e, também, a não se esquecerem do futuro" (GAGNEBIN, 2006, p. 15).

Narrar é uma forma de vencer o esquecimento, a solidão e a distância, é principiar a nostalgia, o regresso (nosto), que possui sempre os olhos voltados para o horizonte, enquanto os pés estão fincados na estrada. Em Terra sonâmbula, o velho Tuahir, de início, se mostra relutante ao ouvir as histórias contadas pelo pequeno Muidinga, que encontrara uma mala onde continha os cadernos de Kindzu. Depois que o pequeno principia a contar as histórias que estavam escondidas naquela mala (uma espécie de tesouro que preenche os dias dos dois exilados), Tuahir pede então que o "miúdo dê voz aos cadernos", que não cesse de contar, pois sabia que: "Não fossem as leituras eles estariam condenados à solidão. Seus devaneios caminhavam agora pelas letrinhas daqueles escritos" (COUTO, 2007, p. 139).

II

Adsiduus generis humani discursus est.

(Sêneca, De Consolatione ad Helviam)

A espécie humana está sempre em contínua mudança. Para Sêneca, esta afirmação é o princípio que fundamenta o frequente

1 Odisseia, canto IX, versos 65-78, tradução de Odorico Mendes, São Paulo: Ars Poetica: Editora da Universidade de São Paulo, 1996, p. 177.

https://periodicos.unifap.br/index.php/letras

Macapá, v. 6, n. I, Io semestre, 2016. 
deslocamento dos povos por "todos os caminhos do mundo"2. Para o filósofo romano, o exilium é, primordialmente, "uma mudança de lugar", definição que, contudo, não atenua suas consequências: pobreza, desonra e desprezo. ${ }^{3}$

Como afirma ainda o filósofo, múltiplas e diferentes causas concorrem para levar os povos a abandonarem sua pátria e procurarem outra:

quem, fugindo às armas inimigas, foi expulso de sua terra e levado, despojado de tudo, para terra estrangeira, pela destruição de sua cidade; quem foi expulso pela guerra civil; quem foi mandado embora pela necessidade de diminuir a população demasiadamente abundante; quem foi obrigado a fugir por uma epidemia ou por frequentes terremotos, ou por qualquer outra causa que tornava o país malsão e inabitável; outros foram seduzidos pela fama de uma região fértil, exageradamente famosa.

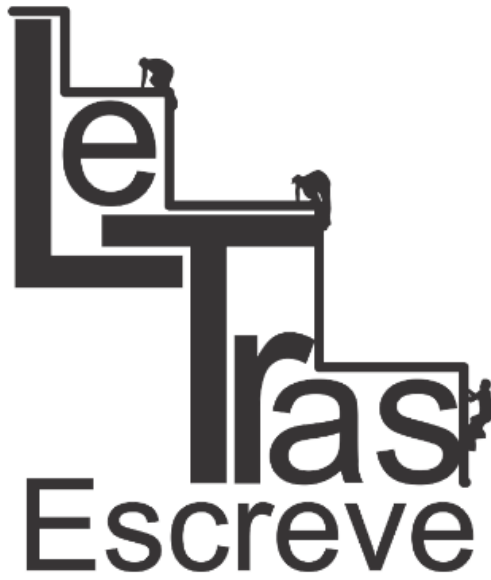

(ISSN 2238-8060)

Aqueles que, pelos motivos elencados por Sêneca, se veem obrigados a abandonar sua pátria, carregam sempre algo de valioso: a Enéias foram confiados os penates, os cultuados deuses troianos que protegiam tanto a esfera doméstica como também o Estado ${ }^{4}$, não somente para que a memória da cidade se mantivesse viva, mas para que ela pudesse renascer em sua glória e resplendor. Por esse motivo, o exílio pode constituir o entrelugar da memória e da reconstrução.

O exilado seria aquele que transforma, paradoxalmente, o mundo em sua pátria? Ao levar consigo os penates, Eneias não somente carrega os objetos sagrados que trazem as lembranças de

2 SÊNECA. "Consolação a minha mãe Hélvia". In: Coleção Os Pensadores. São Paulo: Abril Cultural, 1973, p. 196.

${ }^{3}$ Idem, p. 195.

4 Em nota a tradução de Odorico Mendes da Eneida, de Virgilio, os penates são definidos como: "divindades que protegiam a casa privada e o Estado. Julgavam os romanos que os tinham herdado dos troianos, entre os quais teria surgido seu culto. Na casa, estatuetas que os representavam eram colocadas numa espécie de altar e recebiam oferendas. Enéias é retratado, na epopeia virgiliana, como o herói que salvou os deuses troianos, transportando-os para solo itálico". Nota 63, in: VIRGíLIO. Eneida brasileira: tradução poética da epopeia de Públio Virgílio Maro. Campinas, SP: Editora da UNICAMP, 2008, p. 26. 


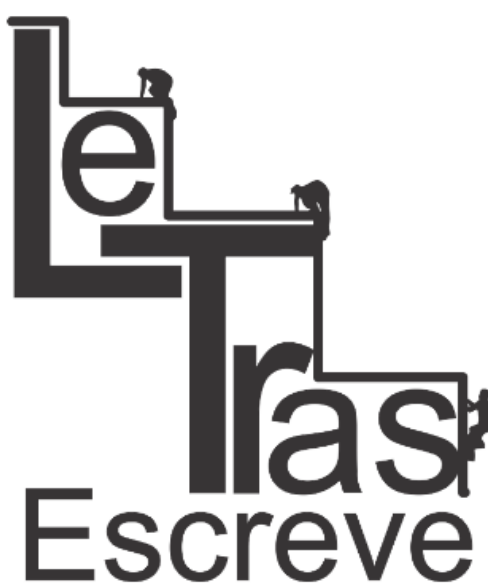

(ISSN 2238-8060)

Tróia, suas crenças, sua religião, mas revela-se, nesse ato, um gesto profundamente simbólico. Os penates eram deuses da esfera doméstica, do lar, da família. Ao serem salvos da destruição, estes deuses passam a acompanhar a viagem dos exilados de Tróia, seu lar passa a ser a longa exilia, até que possam constituir um novo reino, história de onde emerge a grandeza e opulência de Roma, sombra mítica do exílio heroico de Enéias.

O paradoxo, que parece constituir tal indagação, encontra-se na seguinte afirmação de Sêneca: "entre os confins do mundo não há exílio; porque nada daquilo que está dentro dos confins do mundo é estranho ao homem" 5 . Dito de outra maneira: não há estranhamento nos confins do mundo e, somente nesses lugares, o homem seria capaz de sentir-se plenamente em casa. Isso acontece porque nestes confins a reconstrução torna-se essencial; o exilado não precisaria ser radicalmente assimilado (como acontecia, segundo Sêneca, nas grandes cidades; o exilado, depois desse processo de assimilação, adentraria em outra categoria no ordenamento social e jurídico da polis: cosmopolita), mas tornar-seia urgente fundar o altar onde os penates reinariam incontestes. ${ }^{6}$

III

Refugiado, "sem Estado", desterrado, displaced persons e exilado; como afirma Hannah Arendt: "até a terminologia aplicada ao apátrida deteriorou-se" (ARENDT, 1989, p. 313). Tal deterioração não atinge somente o vocabulário político da Europa pós-guerra, mas constitui o epicentro de uma transformação radical dos Estadosnações, colocando impiedosamente à prova a questão dos human

\footnotetext{
${ }^{5}$ SÊNECA, Op. Cit. p. 197.

${ }^{6}$ É preciso, contudo, destacar que a reconstrução está presente tanto no processo de assimilação do exilado na polis, quanto no processo de fundação da civitas fora dela; no entanto, a tensão entre memória e reconstrução parece sempre maior quando o que está em jogo é a transformação das categorias no ordenamento político.
}

https://periodicos.unifap.br/index.php/letras

Macapá, v. 6, n. I, Io semestre, 2016. 
rights e inserindo-se, portanto, no seguinte paradoxo observado pela filósofa alemã:

Nenhum paradoxo da política contemporânea é tão dolorosamente irônico como a discrepância entre os esforços de idealistas bem-intencionados, que persistiam teimosamente em considerar "inalienáveis" os direitos desfrutados pelos cidadãos dos países civilizados, e a situação de seres humanos sem direito algum (ARENDT, 1989, p. 312).

Aqueles que, por excelência, deveriam encarnar os direitos humanos, acabam destacando paradoxalmente a "crise radical desse conceito" (AGAMBEN, 2015, p. 27). Na configuração jurídica e política do Estado-nação não há direitos sagrados e inalienáveis ${ }^{7}$ quando a questão é a garantia de cidadania àqueles que vivem a trágica fratura dos conceitos de humanidade e cidadania: "No sistema do Estado-nação, os assim chamados direitos sagrados e inalienáveis do homem mostram-se desprovidos de toda tutela no próprio momento em que não é mais possível configurá-los como direitos dos cidadãos de um Estado" (AGAMBEN, 2015, p. 27).

Para Giorgio Agamben o exílio não é uma categoria filosófica e política marginal. Pela leitura que perpassa a tradição filosófica grega, de Plotino a Aristóteles, com a Declaração Universal dos Direitos do Homem e do Cidadão, com a experiência das duas grandes guerras no século $X X$ e também pela compreensão filosófica contemporânea, que redimensiona a relação entre o ordenamento jurídico e político e os limites dos conceitos universalizantes de "humanidade", "cidadania" e "direitos humanos", 8

7 "Os Direitos do Homem, afinal, haviam sido como "inalienáveis" porque se supunha serem independentes de todos os governos; mas sucedia que, no momento em que seres humanos deixavam de ter um governo próprio, não restava autoridade para protege-los e nenhuma instituição disposta a garanti-los" (ARENDT, 1989, p. 325).

${ }^{8}$ Destaca-se aqui a importante e original contribuição de Hannah Arendt que pensa o exílio (e as categorias que lhe são inerentes) partindo da relação entre o declínio do Estado-nação e o fim dos direitos humanos. $O$ texto está presente em seu livro Origens do totalitarismo.

https://periodicos.unifap.br/index.php/letras

Macapá, v. 6, n. I, Io semestre, 2016. 
o exílio e seus atores sociais devem ser alçados à condição de protagonistas do teatro político, jurídico e filosófico contemporâneo.

O exilado vive sob o prisma da privação. Esta se manifesta em sua forma mais essencial, que representa a ausência de um "lugar de significação" onde suas opiniões e ações possuam relevância: "a privação fundamental dos direitos humanos manifestase, primeiro e acima de tudo, na privação de um lugar no mundo que torne a opinião significativa e a ação eficaz" (ARENDT, 1989, p. 330). O não pertencimento e o não reconhecimento não são atos passiveis de suas escolhas e ações. Como ressalta Hannah Arendt, a privação extrema não é somente a da liberdade, mas a privação do próprio direito de ação no mundo. ${ }^{9}$

A estrada que agora se abre a nossos olhos não se entrecruza com outra nenhuma. Está mais deitada que os séculos, suportando sozinha toda a distância.

(Mia Couto, Terra sonâmbula)

Em meio as cinzas e a poeira de uma paisagem desolada pela guerra, caminham pela estrada o velho Tuahir e o pequeno Muidinga. Fogem de uma guerra que "contaminara toda a sua terra", levam somente a ilusão de um refúgio seguro, algum lugar onde sonhar ainda seja possível, onde não tenham que conviver, tão intimamente, com a morte. Assim como a estrada, caminham murchos e desesperançados (COUTO, 2007, p. 10).

No meio do caminho encontram uma mala que continha cadernos com as fantásticas histórias de Kindzu e sua odisseia para fugir da guerra civil. Terra sonâmbula poderia, portanto, ser

\footnotetext{
9 "São privados não do seu direito à liberdade, mas do direito à ação; não do direito de pensarem o que quiserem, mas do direito de opinarem. Privilégios (em alguns casos), injustiças (na maioria das vezes), bênçãos ou ruinas lhes serão dados ao sabor do acaso e sem qualquer relação com o que fazem, fizeram ou venham a fazer" (ARENDT, 1989, p. 330).
}

https://periodicos.unifap.br/index.php/letras

Macapá, v. 6, n. I, Io semestre, 2016. 
considerado o encontro entre a vida nua ${ }^{10}$ e um impulso vital que impele para a efabulação, a pulsão de ficção. Tal conceito, formulado por Suzi Sperber, pode ser definido da seguinte maneira:

A pulsão de ficção é a necessidade imperiosa de contar para atribuir um sentido, corrigi-lo, entender, ou tentar compreender. Ao fazer isso, por meios que são mais do que a palavra, são 'performance', com uso de recursos como gestos, movimentos, palavras, linhas, cores, formas no espaço ou na superfície plana, a pulsão de ficção cria imagens, usa símbolos que, comumente, remetem a um passado histórico ou pré-histórico. É que, ao mesmo tempo têm um sentido ancorado no evento pelo enunciador, compreendido pelo receptor a partir da inserção do texto (ou da obra) no contexto do presente histórico, do conhecimento, do pensamento, dos movimentos políticos, econômicos, ideológicos, filosóficos, têm também um lastro no passado histórico - este de duas naturezas: o passado histórico singular, pessoal e o histórico cultural (SPERBER, 2009, p. 577).

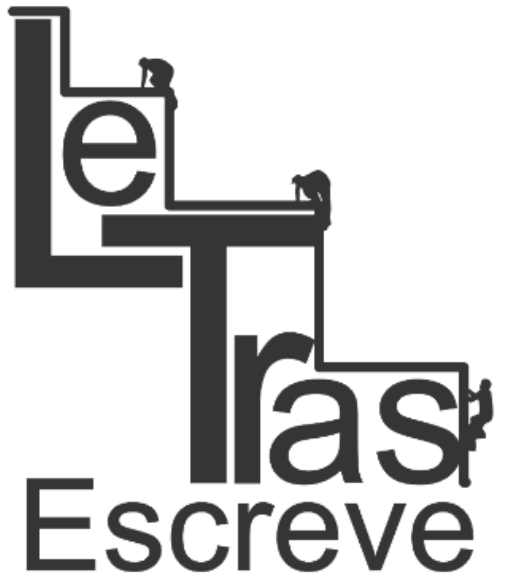

(ISSN 2238-8060)

É na solidão desoladora da vida nua, num mundo sem confins do qual falava Sêneca, que o pequeno leitor Muidinga preenche o exílio dos tempos, com a leitura daquelas histórias tão fascinantes, repletas de sonho, mitologia e efabulação. Nesse sentido, Terra sonâmbula representa uma espécie de artesanato ficcional em contínua tensão com as pulsões de vida e morte. Para o pequeno, o contato com aquelas histórias era uma forma de enfrentar a escuridão e a morte.

Sonâmbulo é aquele que caminha enquanto dorme, seus pés obedecem a um movimento não consciente, como se fossem apanhados por uma força inexplicável que procura algo que vai além dos sonhos. Kindzu, ao conversar com o fantasma de seu pai, é lhe confiada uma revelação:

- Você não sabe, filho. Mas enquanto os homens dormem, a terra anda a procurar.

- A procurar o quê, pai?

10 "(...) a vida nua, que era o fundamento oculto da soberania, tornou-se por toda parte a forma de vida dominante. A vida, no estado de exceção tornado normal, é a vida de sua coesão em uma forma-de-vida." (AGAMBEN, 2015, p. 16).

https://periodicos.unifap.br/index.php/letras

Macapá, v. 6, n. I, Io semestre, 2016. 
- É que a vida não gosta sofrer. A terra anda procurar dentro de cada pessoa, anda juntar os sonhos. Sim, faz conta ela é uma costureira dos sonhos. (COUTO, 2007, p.182)

Sonâmbula é a terra que costura os sonhos e procura no tecido das experiências humanas os retalhos da vida e da ficção. $A$ pulsão de ficção é, portanto, o impulso vital que reelabora a experiência do exílio, é o espaço possível de ressignificação, mediadora entre memória e reconstrução. É neste espaço de latência que os personagens do romance de Mia Couto transitam, seja por estradas e destroços da guerra, ou seja pelo espaço do mito, do sonho e da efabulação.

No artesanato ficcional de Terra sonâmbula, a pulsão de ficção é o impulso que ainda garante dignidade à condição humana do exilado, uma luta contra a "simples existência", contra a vida nua, fundamento não mais oculto da soberania e exclusão. Assim como as qualidades físicas que nos foram atribuídas pelo nascimento, temos este impulso vital que caminha sempre para a superação e que, portanto, garante um estatuto de dignidade humana em luta constante contra todo o tipo de exclusão: "A pulsão de ficção procura uma forma conforme deseja exprimir um impulso para a superação, para a vida, ou a obediência e respeito às normas, tradições, preceitos da coletividade" (SPERBER, 2009, p. 579). Quando a perda de lugar na comunidade torna-se manifesta, a pulsão de ficção devolve os seres humanos ao berço da coletividade.

É caminhando pelas estradas, perseguidos pela morte e refugiando-se nos destroços da guerra, que o velho Tuahir expressa a mais bela afirmação, que nos faz compreender a força vital da pulsão de ficção que luta contra o exílio da vida nua, não à toa constitui uma das epígrafes do romance: "o que faz andar a estrada? É o sonho. Enquanto a gente sonhar a estrada permanecerá viva. É para isso que servem os caminhos, para nos fazerem parentes do futuro". 


\section{Referências bibliográficas}

AGAMBEN, Giorgio. Meios sem fim: notas sobre a política. Tradução de Davi Pessoa Carneiro. Belo Horizonte: Autêntica Editora, 2015.

ARENDT, Hannah Origens do totalitarismo. Tradução de Roberto Raposo. São Paulo: Companhia das Letras, 1989.

COUTO, Mia. Terra sonâmbula. São Paulo: Companhia das Letras, 2007.

GAGNEBIN, Jeanne Marie. Lembrar escrever esquecer. São Paulo: Ed. 34, 2006.

HOMERO. Odisseia. Tradução de Manuel Odorico Mendes; edição de Antônio Medina Rodrigues. São Paulo: Ars Poetica: Editora da Universidade de São Paulo, 1996.

SAID, Edward D. Reflexões sobre o exílio e outros ensaios. Tradução de Pedro Maia Soares. São Paulo: Companhia das letras, 2003.

SÊNECA. "Consolação a minha mãe Hélvia". In: Coleção os Pensadores. São Paulo: Abril S.A., 1973.

SPERBER, Suzi Frankl. Ficção e razão: uma retomada das formas simples. São Paulo: Aderaldo \& Rothschild: Fapesp, 2009.

VIRGÍLIO. Eneida brasileira: tradução poética da epopeia de Públio Virgílio Maro. Organização de Paulo Sérgio de Vasconcelos et al. Campinas, SP: Editora da UNICAMP, 2008.

Recebido em 04/06/2016. Aprovado em 17/07/2016. 